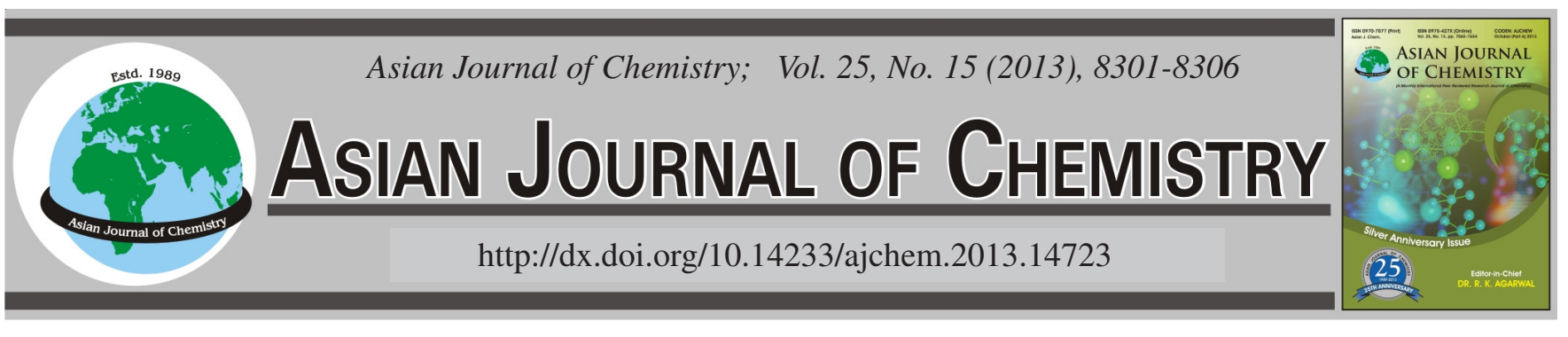

\title{
Kinetic and Thermodynamic Studies for Methylene Blue Adsorption using Activated Carbon Prepared from Agricultural and Municipal Solid Wastes
}

\author{
Zeid Abdullah Al-Othman ${ }^{1}$, Mohamed Abdelaty Habila ${ }^{1, *}$, Rahmat Ali ${ }^{1}$ and Mohamed Salah El-Din Hassouna ${ }^{2}$
}

\begin{abstract}
${ }^{1}$ Advanced Materials Research Chair to Affliction, Department of Chemistry, College of Science, King Saud University, P.O. Box 2455, Riyadh 11451, Kingdom of Saudi Arabia

${ }^{2}$ Department of Environmental Studies, Institute of Graduate Studies and Research, Alexandria University, 163 El-Horreya Avenue, P.O. Box 832, Alexandria, Egypt
\end{abstract}

*Corresponding author: Tel: +966 595184785; E-mail: mhabila@ksu.edu.sa

(Received: 20 October 2012;

Accepted: 19 August 2013)

AJC-13938

\begin{abstract}
This study aimed to evaluate and optimize the removal of methylene blue onto low cost starting material activated carbon. The effects of $\mathrm{pH}$, contact time, initial concentration on adsorption process were investigated. Results showed that effective adsorption was occurred in the $\mathrm{pH}$ range of $5-12$. The maximum adsorption capacity $(140.03 \mathrm{mg} / \mathrm{g})$ was obtained at contact time $480 \mathrm{~min}$, at initial methylene blue concentration of $150 \mathrm{ppm}$. Adsorption kinetics of methylene blue was analyzed by pseudo first order, pseudo second order and intraparticle diffusion models. Results showed that methylene blue adsorption onto activated carbon followed second order kinetics models most appropriately. Thermodynamic parameters; $\Delta \mathrm{G}^{\circ}, \Delta \mathrm{H}^{\circ}$ and $\Delta \mathrm{S}^{\circ}$ indicate that the sorption process was spontaneous and endothermic in nature. The magnitude of $\Delta \mathrm{G}^{\circ}$ was -6.27 to $-12 \mathrm{~kJ} / \mathrm{mol}$, the standard enthalpy and the entropy values in the range of $25-50{ }^{\circ} \mathrm{C}$ were obtained as $44.13 \mathrm{~kJ} \mathrm{~mol}^{-1}$ and $158.3 \mathrm{~kJ} \mathrm{~mol}^{-1} \mathrm{~K}^{-1}$.
\end{abstract}

Key Words: Copyrolysis, Municipal solid waste, Chemical activation, Activated carbon, Adsorption, Kinetic models.

\section{INTRODUCTION}

The removal of dyes from waste effluents is considered as an environmental need because they can be visible and highly toxic even at very low concentration levels ${ }^{1}$. Dyes contaminate environment from various industries, like textiles, paper, cosmetics, printing and foods. Dyes can destroy aquatic life because they prevent sunlight from reching water bottom totally. Also dyes may be mutagenic and/or carcinogenic to human ${ }^{2}$. Usually, methylene blue is used for cotton and wood. Methylene blue can cause eye damage for human and animals. On inhalation, it may lead to short periods of rapid or difficult breathing; ingestion may cause nausea and methemoglobinemia $^{3}$. Many methods are used to remove colour from industrial effluents such as biological biodegradation ${ }^{4}$ and adsorption ${ }^{5}$.

Many previous works studied the removal of methylene blue using different adsorbent such as coffee husks ${ }^{6}$, yellow passion fruit waste ${ }^{7}$, rice husks ${ }^{8}$, banana peel ${ }^{9}$, cereal chaff $^{10}$, spent coffee grounds ${ }^{11}$, orange peel ${ }^{9}$, wheat shells ${ }^{12}$, durian peel $^{13}$, etc. The application of untreated agricultural or plant waste as adsorbents, in addition to its low adsorption efficiency, may lead to additional organic load in the treated effluent in the form of chemical oxygen demand (COD), biological oxygen demand (BOD) and total organic carbon (TOC) due to release of soluble organic compounds contained in the plant wastes ${ }^{14}$. Activated carbon is mostly used for commercial systems ${ }^{15,16}$, but limitedly used because of its high operating costs ${ }^{17,18}$. To reduce the production cost, the utilization of renewable and less expensive precursors for the preparation of activated carbon is attracting the interest of researchers all over the world. The precursors of interest are primarily industrial and agricultural byproducts and forest wastes, such as coconut shell ${ }^{19}$, sugar beet bagasse ${ }^{20}$, rice straw ${ }^{21}$, rubber wood sawdust ${ }^{22}$ and coconut husk ${ }^{23}$. Waste plastics and tires, which are organic materials, can also be converted into activated carbon. Several experimental studies ${ }^{24,25}$ have reported the production of char and activated carbon from waste tires. The potential of these products as possible adsorbents of various pollutants has been assessed and found to be very great. Also the disposed solid waste (SW) may be used as precursor in the production of a low cost adsorbent to treat wastewater contaminated with heavy metals and refractory compounds ${ }^{26}$. The conversion of locally available solid wastes such as biomass, waste cartons, waste news papers, plastics and industrial byproducts into activated carbon for wastewater treatment would improve the economic value by providing an alternative to costly activated carbon ${ }^{27,28}$. Pyrolysis is one of the ways to take advantage of the energetic and organic value of these waste materials. Many authors have 
studied the pyrolysis of biomass and plastic waste and have demonstrated that it is a suitable method of waste processing ${ }^{29,30}$. The goals of this study were to optimize the adsorption factors affecting removal of methylene blue from aqueous solutions. Our previously prepared activated carbon from mixed wastes (biomass, waste cartons and poly styrene) by chemical activation with $\mathrm{ZnCl}_{2}$ was used as an adsorbent ${ }^{28}$. The sorption process was examined in terms of kinetics and thermodynamics. Batch adsorption experiments were conducted to evaluate the sorption process over a wide range of operation conditions for sorbate concentration, $\mathrm{pH}$, contact time and sorbent dose. The adsorption capacity at the optimum condition was compared to other adsorbent from the literature.

\section{EXPERIMENTAL}

Raw materials and activated carbon preparation: The precursors used in this study were trunks of palm trees, waste cartons and poly styrene collected from a municipal solid waste station in Riyadh, Saudi Arabia. In this study, the three-stage process was used for the preparation of activated carbon from mixed wastes. In this process, the precursors are carbonized, impregnated with $\mathrm{ZnCl}_{2}$ and then activated for a specific period of time as described in our previous work ${ }^{28}$.

Methylene blue (MB), $\mathrm{C}_{16} \mathrm{H}_{18} \mathrm{CIN}_{3} \mathrm{~S} \cdot 3 \mathrm{H}_{2} \mathrm{O}$ (Fig. 1) supplied by Sigma Aldrich was used as an adsorbate. Stock solution was prepared by dissolving $1 \mathrm{~g}$ of methylene blue in $2 \mathrm{~L}$ distilled water.

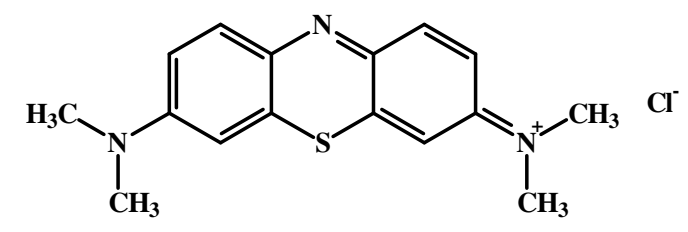

Fig. 1. Structure of methylene blue

Batch adsorption studies: The adsorption capacity of the activated carbon was evaluated using methylene blue as an adsorbate. The adsorption was determined using a batch method, which allows for the convenient evaluation of parameters that influence the adsorption process. A stock solution of methylene blue $(1000 \mathrm{mg} / \mathrm{L})$ was prepared in double-distilled water and further diluted to the desired concentrations. The batch adsorption experiments were performed in $250 \mathrm{~mL}$ conical flasks by mixing $80 \mathrm{~mL}$ of the methylene blue solution with $0.03 \mathrm{~g}$ of activated carbon and then equilibrated in a thermostat-cumshaking assembly (model MSW 275) at $30^{\circ} \mathrm{C}$ and $200 \mathrm{rpm}$. After equilibrating, the concentration of remaining methylene blue in the solution was measured using a UV-visible spectrophotometer (UV-30 LC, Thermo Scientific, England) at $\lambda_{\max }=$ 665 . The amount of methylene blue per unit weight of adsorbent, $\mathrm{q}_{\mathrm{e}}(\mathrm{mg} / \mathrm{g})$, was calculated using the following equation:

$$
\mathrm{q}_{\mathrm{e}}=\frac{\mathrm{V}\left(\mathrm{C}_{\mathrm{o}}-\mathrm{C}_{\mathrm{e}}\right)}{\mathrm{W}}
$$

where $C_{o}$ and $C_{e}$ are the initial and equilibrium concentrations of methylene blue in solution $(\mathrm{mg} / \mathrm{L}), \mathrm{V}$ is the solution volume $(\mathrm{L}), \mathrm{W}$ is the weight of the adsorbent $(\mathrm{g})$ and $\mathrm{q}_{\mathrm{e}}$ is the adsorption capacity $(\mathrm{mg} / \mathrm{g})$.
The effect of the initial $\mathrm{pH}$ on the removal of methylene blue was examined over the $\mathrm{pH}$ range of 2-12 using $80 \mathrm{~mL}$ solutions with a methylene blue concentration of $50 \mathrm{mg} / \mathrm{L}$. The solution $\mathrm{pH}$ was adjusted to the desired value by the addition of $0.1 \mathrm{M} \mathrm{HCl}$ or $\mathrm{NaOH}$.

The effect of shaking time on the adsorption of methylene blue was examined at three different initial concentrations (40, $80,120 \mathrm{mg} / \mathrm{L}$ ) of methylene blue at $30^{\circ} \mathrm{C}, 0.03 \mathrm{~g}$ of adsorbent and the selected $\mathrm{pH}$. At predetermined times; the solution of the specified flask was filtered using Whatman No. 42 filter paper and analyzed using a UV-visible spectrophotometer.

\section{Adsorption kinetic models}

Lagergren-first-order equation: Lagergren-first-order equation is the most popular kinetics equation ${ }^{31}$. The form is

$$
\frac{\mathrm{dq}_{\mathrm{t}}}{\mathrm{dt}}=\mathrm{k}_{1}\left(\mathrm{q}_{\mathrm{e}}-\mathrm{q}_{\mathrm{t}}\right)
$$

where $\mathrm{q}_{\mathrm{e}}$ and $\mathrm{q}_{\mathrm{t}}$ are the sorption capacities at equilibrium and at time $\mathrm{t}$, respectively, $(\mathrm{mg} / \mathrm{g})$ and $\mathrm{k}_{1}$ is the rate constant of pseudo first-order sorption $\left(\mathrm{min}^{-1}\right)$. After integration and applying initial conditions, $\mathrm{q}_{\mathrm{t}}=0$ to $\mathrm{q}_{\mathrm{t}}=\mathrm{q}_{\mathrm{t}}$ at $\mathrm{t}=0$ to $\mathrm{t}=\mathrm{t}$, the integrated form of eqn. 2 becomes:

$$
\log \left(q_{e}-q_{t}\right)=\log q_{e}-\frac{k_{1} t}{2.303}
$$

The adsorption rate constant $\mathrm{k}_{1}$, can be determined experimentally by plotting of $\ln \left(\mathrm{q}_{\mathrm{e}}-\mathrm{q}_{\mathrm{t}}\right)$ versus $\mathrm{t}$.

Pseudo-second-order equation: The pseudo-secondorder chemisorption kinetic rate equation is expressed $\mathrm{as}^{32}$ :

$$
\frac{\mathrm{dq}_{\mathrm{t}}}{\mathrm{dt}}=\mathrm{k}_{2}\left(\mathrm{q}_{\mathrm{e}}-\mathrm{q}_{\mathrm{t}}\right)^{2}
$$

where $\mathrm{q}_{\mathrm{e}}$ and $\mathrm{q}_{\mathrm{t}}$ are the sorption capacities at equilibrium and at time $\mathrm{t}$, respectively, $(\mathrm{mg} / \mathrm{g})$ and $\mathrm{k}_{2}$ is the rate constant of pseudo-second-order sorption $(\mathrm{g} /(\mathrm{mg} \mathrm{min}))$. After integration and applying initial conditions, $\mathrm{q}_{\mathrm{t}}=0$ to $\mathrm{q}_{\mathrm{t}}=\mathrm{q}_{\mathrm{t}}$ at $\mathrm{t}=0$ to $\mathrm{t}=\mathrm{t}$, the integrated form of eqn. 4 becomes:

$$
\frac{\mathrm{t}}{\mathrm{dt}}=\frac{1}{\mathrm{Kq}_{\mathrm{e}}^{2}}+\frac{1 \mathrm{t}}{\mathrm{q}_{\mathrm{e}}}
$$

where $\mathrm{t}$ is the contact time $(\mathrm{min})$ and $\mathrm{q}_{\mathrm{e}}(\mathrm{mg} / \mathrm{g})$ and $\mathrm{q}^{2}(\mathrm{mg} / \mathrm{g})$ are the amount of the solute adsorbed at equilibrium.

Intraparticle diffusion model: The intraparticle diffusion model was tested to identify the diffusion mechanism ${ }^{33}$, is expressed as:

$$
\mathrm{q}_{\mathrm{t}}=\mathrm{k}_{\mathrm{id}} \mathrm{t}^{1 / 2}+\mathrm{C}
$$

where $\mathrm{k}_{\mathrm{id}}$ is the intraparticle diffusion rate constant $(\mathrm{mg} / \mathrm{g}$ $\left.\min ^{1 / 2}\right), \mathrm{C}$ is the intercept ( $\mathrm{mg} / \mathrm{g}$ ).

The plot of $\mathrm{q}_{\mathrm{t}}$ versus $\mathrm{t}^{1 / 2}$ gave straight line and the values of $\mathrm{k}_{\mathrm{id}}$ were calculated from the slopes of the plots. Values of $\mathrm{C}$ gave an idea about the thickness of boundary layer, i.e., the larger the intercept, greater the contribution of the surface sorption in the rate controlling step.

Effect of methylene blue concentration and DubininRadushkevich (D-R) model: The effect of methylene blue concentration on the adsorption capacity examined at three different initial concentrations $(5,10,20,30,40,50,100,150$ $\mathrm{mg} / \mathrm{L}$ ) of methylene blue at $30^{\circ} \mathrm{C}, 0.03 \mathrm{~g}$ of adsorbent and the 
selected $\mathrm{pH}$. The adsorption data was also modeled by D-R isotherm to determine the adsorption type (physical or chemical $)^{34,35}$. The linear form of this model is expressed in eqn. 7

$$
\ln \mathrm{q}_{\mathrm{e}}=\ln \mathrm{q}_{\mathrm{m}}-\beta \varepsilon^{2}
$$

where $\mathrm{q}_{\mathrm{e}}$ is the amount of the metal adsorbed onto per unit dosage of the adsorbent ( $\mathrm{mol} / \mathrm{L}) ; \mathrm{q}_{\mathrm{m}}$, the monolayer adsorption capacity $(\mathrm{mol} / \mathrm{g}) ; \beta$, the activity coefficient related to mean sorption energy $\left(\mathrm{mol}^{2} / \mathrm{J}^{2}\right)$ and $\varepsilon$ is the Polanyi potential $(\varepsilon=$ $\left.\mathrm{RT} \ln \left(1+1 / \mathrm{C}_{\mathrm{e}}\right)\right)^{34,35}$. The mean sorption energy $\mathrm{E}(\mathrm{kJ} / \mathrm{mol})$, can be calculated using eqn. 8

$$
E=\frac{1}{\sqrt{2 \beta}}
$$

Thermodynamic studies: Thermodynamic parameters, such as change in Gibbs free energy $\left(\Delta \mathrm{G}^{\mathrm{o}}\right)$, enthalpy $\left(\Delta \mathrm{H}^{\circ}\right)$ and entropy $\left(\Delta S^{\circ}\right)$, were evaluated using eqns. 9 and 10 :

$$
\begin{gathered}
\log \mathrm{K}_{\mathrm{d}}=\frac{\Delta \mathrm{S}^{\mathrm{o}}}{2.303 \mathrm{R}}-\frac{\Delta \mathrm{H}^{\mathrm{o}}}{2.303 \mathrm{RT}} \\
\Delta \mathrm{G}^{\mathrm{o}}=-\mathrm{RT} \ln \mathrm{K}_{\mathrm{d}}
\end{gathered}
$$

where $K_{d}$ is the equilibrium partition constant calculated as the ratio between sorption capacity $\left(\mathrm{q}_{\mathrm{e}}\right)$ and equilibrium concentration $\left(\mathrm{C}_{\mathrm{e}}\right), \mathrm{R}$ is the gas constant $(8.314 \mathrm{~J} / \mathrm{mol} / \mathrm{K})$ and $\mathrm{T}$ is the temperature in Kelvin $(\mathrm{K})$. From eqn. 9 a plot of $\log$ $\mathrm{K}_{\mathrm{d}}$ versus $1 / \mathrm{T}$ (Fig. 8) give $\Delta \mathrm{H}^{\mathrm{o}}$ and $\Delta \mathrm{S}^{\mathrm{o}}$.

\section{RESULTS AND DISCUSSION}

Effect of pH: The pH of aqueous solution is one of the most important factors that influence the adsorption of dyes due to its impact on both the surface binding-sites of the adsorbent and the ionization process of the dye molecule ${ }^{36}$. The adsorption of methylene blue was studied as a function of $\mathrm{pH}$ over a $\mathrm{pH}$ range of 2-12 onto the activated carbon at initial concentration of 100 ppm, as shown in Fig. 2. It is clear that the adsorption capacity presented a slight increase with increasing the $\mathrm{pH}$, but there is no significant change in the percentage removal of methylene blue over the whole $\mathrm{pH}$ range. After $24 \mathrm{~h}$, the adsorption capacity was $56.02 \%$ at $\mathrm{pH}$ $=2$ and presented an average of $66.37 \%$ in the $\mathrm{pH}$ range of 4-12. This may be due to the formation of more functional groups on the surface of activated carbon which increase their surface complexation capability.

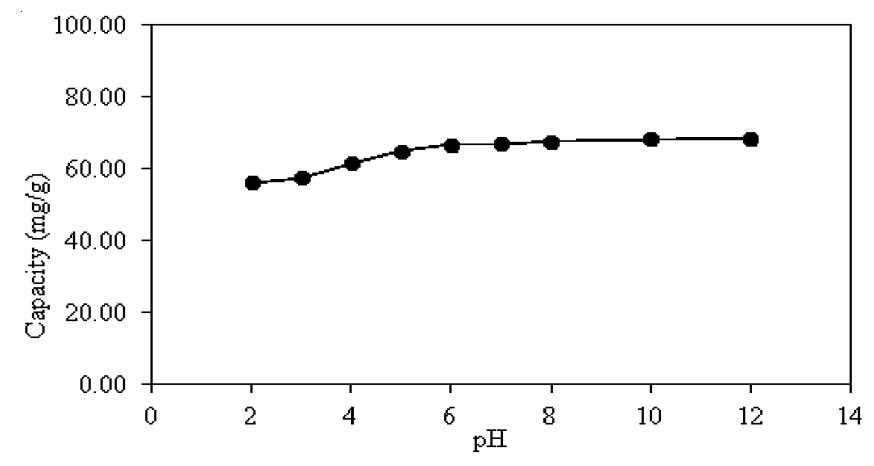

Fig. 2. Effect of $\mathrm{pH}$ on methylene blue adsorption onto activated carbon prepared from mixed wastes at low carbonization temperature of $200{ }^{\circ} \mathrm{C}$, followed by activation with $2 \mathrm{M} \mathrm{ZnCl}_{2}$ solution
Effect of contact time: The amount of methylene blue adsorbed onto activated carbon was studied as a function of the shaking time at different initial concentrations at $30^{\circ} \mathrm{C}$ and desired $\mathrm{pH}$. The effect of contact time for three different concentrations $(40,80,120 \mathrm{ppm})$ of methylene blue adsorption by activated carbon is given in Fig. 3. It is evident from the figure that the amount of methylene blue adsorbed increases with increasing contact time. Further, the adsorption was rapid in the early stages and then gradually decreased to become constant after the equilibrium point. The saturation point is almost reached at $480 \mathrm{~min}$. At this point, the amount of dye desorbing from the activated carbon is in a state of dynamic equilibrium with the amount of the dye being adsorbed on the activated carbon. The amount of dye adsorbed at the equilibrium time reflects the maximum adsorption capacity of the adsorbent. The removal of methylene blue was found to be dependent upon the initial concentration. The amount of methylene blue adsorbed, $\mathrm{q}_{\mathrm{e}}(\mathrm{mg} / \mathrm{g})$, increased with an increase in the initial concentration. In this study, the amount of methylene blue adsorbed at equilibrium increased from $70.15-122.23 \mathrm{mg} / \mathrm{g}$ with the increase in the initial dye concentration from 40-120 ppm. The mass transfer driving force becomes larger when the initial concentration increased and hence resulting in higher adsorption of methylene blue. At low concentrations, the ratio of available surface to initial methylene blue concentration is larger, so the removal becomes independent of the initial concentration. However, in the case of higher concentrations, this ratio is low and the percentage removal depends upon the initial concentration.

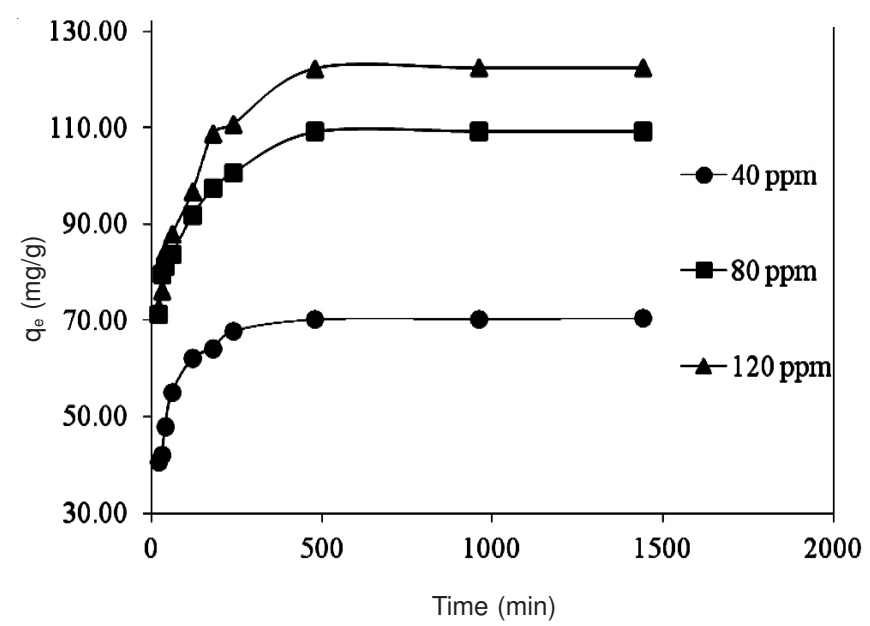

Fig. 3. Effect of contact time on methylene blue adsorption onto activated carbon prepared from mixed wastes at low carbonization temperature of $200{ }^{\circ} \mathrm{C}$, followed by activation with $2 \mathrm{M} \mathrm{ZnCl}_{2}$ solution

Batch kinetic studies: Adsorption kinetics provides valuable information about the reaction pathways and mechanism of the reactions. In order to examine the controlling mechanism of the adsorption process, the pseudo first-order, pseudo secondorder and intraparticle diffusion models $\mathrm{s}^{31-33}$ were applied to analyze the experimental data of adsorption of methylene blue on the prepared activated carbon. The conformity between experimental data and the model predicted values was expressed by the correlation coefficients $\left(\mathrm{R}^{2}\right)$. 
Pseudo-first order kinetic model: The linearizedintegral form of the pseudo first-order model ${ }^{31}$, is generally expressed as:

$$
\log \left(q_{e}-q_{t}\right)=\log q_{e}-\frac{k_{1} t}{2.303}
$$

where $\mathrm{q}_{\mathrm{e}}$ and $\mathrm{q}_{\mathrm{t}}$ are the amounts of adsorbed of methylene blue $(\mathrm{mg} / \mathrm{g})$ at equilibrium and at time $\mathrm{t}$, respectively and $\mathrm{k}_{1}$ is the rate constant of first order adsorption $\left(\mathrm{min}^{-1}\right)$. Straight lines were obtained by plotting $\log \left(\mathrm{q}_{\mathrm{e}}-\mathrm{q}_{\mathrm{t}}\right)$ against $\mathrm{t}$, as shown in Fig. 4. The values of the rate constant $\mathrm{k}_{1}$ and $\mathrm{q}_{\mathrm{e}}$ at three different initial concentrations were obtained from the slopes and intercepts of the plots, respectively and presented in Table- 1 . Results showed that there are differences between the experimental $\mathrm{q}_{\mathrm{e}}(70.15,109.16$ and $122.23 \mathrm{mg} / \mathrm{g})$ and the calculated $\mathrm{q}_{\mathrm{e}}(65.8,52.5$ and $59.2 \mathrm{mg} / \mathrm{g})$ in case of initial methylene blue dye concentration of 40, 80 and 120 ppm, respectively.

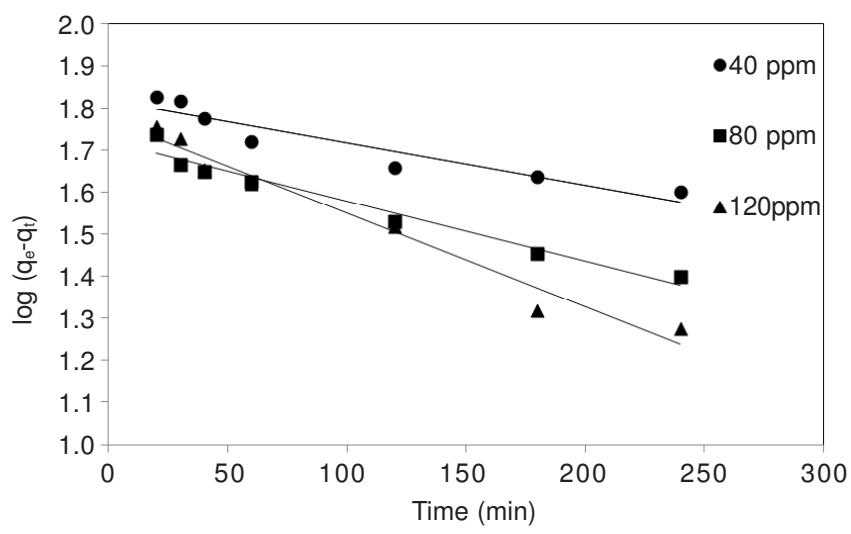

Fig. 4. Lagergren first order plot for methylene blue adsorption onto activated carbon prepared from mixed wastes at low carbonization temperature of $200{ }^{\circ} \mathrm{C}$, followed by activation with $2 \mathrm{M} \mathrm{ZnCl}_{2}$ solution

Pseudo second-order kinetic model: The parameters of pseudo second-order adsorption kinetic model can be determined from eqn. 5

$$
\frac{\mathrm{t}}{\mathrm{q}_{\mathrm{t}}}=\frac{1}{\mathrm{k}_{2} \mathrm{q}_{\mathrm{e}}^{2}}+\frac{\mathrm{t}}{\mathrm{q}_{\mathrm{e}}}
$$

The plots of $\mathrm{t} / \mathrm{q}_{\mathrm{t}}$ versus $\mathrm{t}$ of eqn. 6 gave linear plots Fig. 5 . The values of $\mathrm{q}_{\mathrm{e}}$ and $\mathrm{k}_{2}$ were determined from the slopes and intercepts of the plots, respectively and are listed in Table- 1 . Good agreement are obtained between the experimental $\mathrm{q}_{\mathrm{e}}$ $(70.15,109.16$ and $122.23 \mathrm{mg} / \mathrm{g})$ and the calculated $\mathrm{q}_{\mathrm{e}}(71.4$, 111.1 and $125 \mathrm{mg} / \mathrm{g}$ ) in case of initial methylene blue dye concentration of 40,80 and 120 ppm respectively.

Intraparticle diffusion model: The intraparticle diffusion model was tested to identify the diffusion mechanism, is expressed as in eqn. 6 :

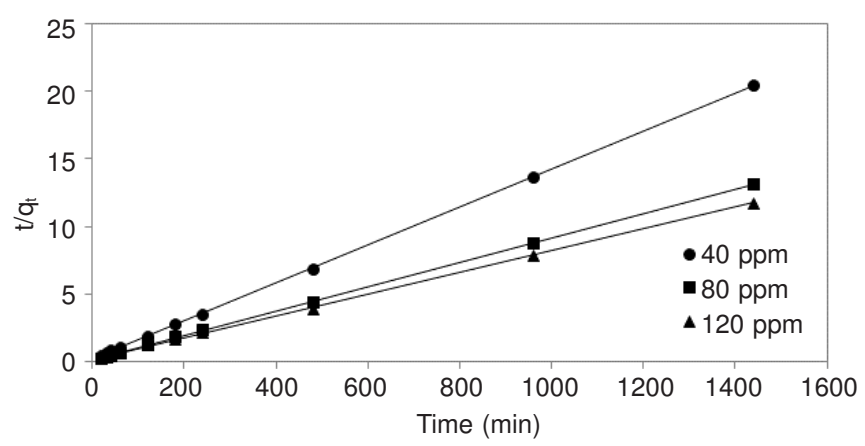

Fig. 5. Pseudo-second order plot for methylene blue adsorption onto activated carbon prepared from mixed wastes at low carbonization temperature of $200{ }^{\circ} \mathrm{C}$, followed by activation with $2 \mathrm{M} \mathrm{ZnCl}_{2}$ solution

$$
\mathrm{q}_{\mathrm{t}}=\mathrm{k}_{\mathrm{id}_{\mathrm{d}}} \mathrm{t}^{1 / 2}+\mathrm{C}
$$

where $\mathrm{k}_{\mathrm{id}}$ is the intraparticle diffusion rate constant $(\mathrm{mg} / \mathrm{g}$ $\left.\min ^{1 / 2}\right), \mathrm{C}$ is the intercept $(\mathrm{mg} / \mathrm{g})$.

The plot of $\mathrm{q}_{\mathrm{t}}$ versus $\mathrm{t}^{1 / 2}$ gave straight line and the values of $\mathrm{k}_{\mathrm{id}}$ were calculated from the slopes of the plots. Values of $\mathrm{C}$ gave an idea about the thickness of boundary layer, i.e., the larger the intercept, greater the contribution of the surface sorption in the rate controlling step. The data for methylene blue adsorption onto activated carbons applied to intraparticle diffusion model is shown in Fig. 6 and the results are given in Table-1.

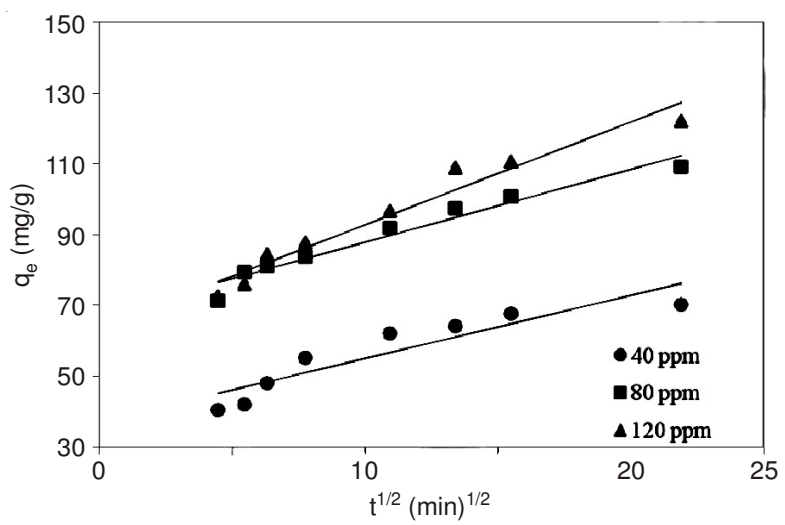

Fig. 6. Intraparticle diffusion model plot for methylene blue adsorption onto activated carbon prepared from mixed wastes at low carbonization temperature of $200{ }^{\circ} \mathrm{C}$, followed by activation with 2 $\mathrm{M} \mathrm{ZnCl}{ }_{2}$ solution

It is clear from Table-1 that among these three models, pseudo-second order kinetic equations had high $\mathrm{R}^{2}$ values and also the experimental $\mathrm{q}_{\mathrm{e}}$ is in accordance with calculated $\mathrm{q}_{\mathrm{e}}$. The low values of $\mathrm{R}^{2}$ for pseudo-first order and intra particle diffusion models indicated apparently that these models did not fit the data well. Furthermore, for pseudo-first order kinetic

TABLE-1

KINETIC CONSTANT PARAMETERS OBTAINED FOR MB ADSORPTION ON ACTIVATED CARBON PREPARED FROM MIXED WASTES AT LOW CARBONIZATION TEMPERATURE OF $200^{\circ} \mathrm{C}$, FOLLOWED BY ACTIVATION WITH $2 \mathrm{M} \mathrm{ZnCl}_{2}$ SOLUTION

\begin{tabular}{cccccccccccc}
\hline & \multicolumn{4}{c}{ Pseudo-first order } & \multicolumn{3}{c}{ Pseudo-second order } & \multicolumn{4}{c}{ Intraparticle diffusion model } \\
\hline $\mathrm{C}_{\mathrm{i}}(\mathrm{ppm})$ & $\begin{array}{c}\mathrm{q}_{\mathrm{e}, \mathrm{exp}} \\
(\mathrm{mg} / \mathrm{g})\end{array}$ & $\begin{array}{c}\mathrm{K}_{1}\left(10^{-3}\right) \\
\left(\mathrm{min}^{-1}\right)\end{array}$ & $\begin{array}{c}\mathrm{q}_{\mathrm{e}, \mathrm{cal}} \\
(\mathrm{mg} / \mathrm{g})\end{array}$ & $\mathrm{R}^{2}$ & $\begin{array}{c}\mathrm{k}_{2}\left(10^{-4}\right) \\
(\mathrm{g} / \mathrm{mg} \min )\end{array}$ & $\begin{array}{c}\mathrm{q}_{\mathrm{e}, \text { cal }} \\
(\mathrm{mg} / \mathrm{g})\end{array}$ & $\begin{array}{c}\mathrm{h}(\mathrm{mg} / \mathrm{g} \\
\mathrm{min})\end{array}$ & $\mathrm{R}^{2}$ & $\begin{array}{c}\mathrm{k}_{\text {id }} \\
(\mathrm{mg} / \mathrm{g} \cdot \mathrm{min})\end{array}$ & $\begin{array}{c}\mathrm{C} \\
(\mathrm{mg} / \mathrm{g})\end{array}$ & $\mathrm{R}^{2}$ \\
\hline 40 & 70.15 & 2.303 & 65.856 & 0.892 & 8.292 & 71.428 & 4.081 & 0.999 & 1.784 & 37.110 & 0.842 \\
80 & 109.16 & 3.224 & 52.505 & 0.962 & 5.291 & 111.11 & 6.173 & 0.999 & 2.065 & 67.185 & 0.953 \\
120 & 122.23 & 5.066 & 59.265 & 0.968 & 3.585 & 125.00 & 5.594 & 0.999 & 2.895 & 63.882 & 0.952 \\
\hline
\end{tabular}


model the experimental $\mathrm{q}_{\mathrm{e}}$ are not in good agreement with calculated $\mathrm{q}_{\mathrm{e}}$. In the view of these results, it can be said that the pseudo second order kinetic model provided a good correlation for the description of the mechanism of sorption of methylene blue in contrast to the other models.

Effect of initial methylene blue concentration and D-R model: Results presented in Table-2 shows the effect of initial methylene blue concentration on the adsorption capacity by mixed waste activated carbon. The adsorption capacity increases from 10 to $141.03 \mathrm{mg} / \mathrm{g}$ with increasing initial methylene blue concentration from $5-150 \mathrm{ppm}$, at $30^{\circ} \mathrm{C}$, contact time 480 min. The increase in the adsorption capacity may be due to enhanced driving force, i.e., the concentration gradient. These results are in agreement with that reported by Oliveira et al. ${ }^{6}$.

\section{TABLE-2}

SHOWS THE EFFECT OF INITIAL METHYLENE BLUE CONCENTRATION ON THE ADSORPTION CAPACITY

\begin{tabular}{cccc}
\hline $\begin{array}{c}\text { Initial } \\
\text { methylene blue } \\
\text { conc. }(\mathrm{ppm})\end{array}$ & $\begin{array}{c}\text { Adsorption } \\
\text { capacity } \mathrm{q}_{\mathrm{e}} \\
(\mathrm{mg} / \mathrm{g})\end{array}$ & $\begin{array}{c}\text { Initial } \\
\text { methylene blue } \\
\text { conc. }(\mathrm{ppm})\end{array}$ & $\begin{array}{c}\text { Adsorption } \\
\text { capacity } \mathrm{q}_{\mathrm{e}} \\
(\mathrm{mg} / \mathrm{g})\end{array}$ \\
\hline 5 & 10 & 50 & 87.02 \\
10 & 20 & 80 & 114.50 \\
20 & 40 & 100 & 121.50 \\
30 & 51.08 & 150 & 141.03 \\
40 & 69.30 & - & - \\
\hline
\end{tabular}

The adsorption data were also applied to the D-R isotherm model based on the heterogeneous surface of the adsorbate to differentiate between physical and chemical adsorption. Fig. 7 shows the D-R isotherm plot for the adsorption of methylene blue onto mixed waste activated carbon. The correlation coefficient $\mathrm{R}^{2}$ is 0.971 . The $\beta$ constant and $\mathrm{q}_{\mathrm{m}}$ were calculated from the slopes and intercept of the plot. The $\beta$ constant and the $\mathrm{q}_{\mathrm{m}}$ value were found to be $8.8 \times 10^{-3} \mathrm{~mol}^{2} / \mathrm{kJ}^{2}$ and $0.403 \mathrm{~mol} / \mathrm{g}$, respectively. The mean free energy of adsorption E gives information about adsorption mechanism as chemical ion-exchange or physical adsorption. If $E$ value is between 8 and $16 \mathrm{~kJ} / \mathrm{mol}$, the adsorption process follows by chemical ion exchange and if $\mathrm{E}<8 \mathrm{~kJ}$ mol, the adsorption is physical in nature ${ }^{34,35}$. From eqn. 8, the numerical value of $E$ was calculated as $5.33 \mathrm{~kJ} / \mathrm{mol}$ indicating the adsorption process may be carried out via physical interaction including van der waals forces.

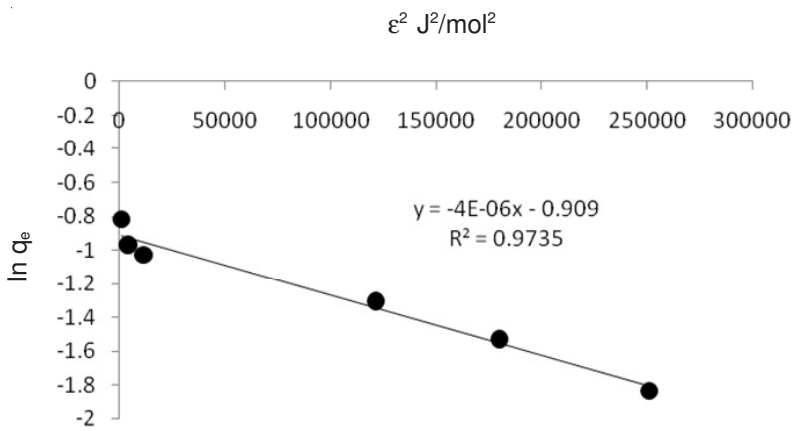

Fig. 7. Shows the D-R isotherm plot for the adsorption of methylene blue onto mixed waste activated carbon

Thermodynamic studies: Thermodynamic parameters, such as change in Gibbs free energy $\left(\Delta \mathrm{G}^{\mathrm{o}}\right)$, enthalpy $\left(\Delta \mathrm{H}^{\circ}\right)$ and entropy $\left(\Delta S^{\circ}\right)$, were evaluated using eqns. 8 and 9 :

$$
\begin{gathered}
\log \mathrm{K}_{\mathrm{d}}=\frac{\Delta \mathrm{S}^{\mathrm{o}}}{2.303 \mathrm{R}}-\frac{\Delta \mathrm{H}^{\mathrm{o}}}{2.303 \mathrm{RT}} \\
\Delta \mathrm{G}^{\mathrm{o}}=-\mathrm{RT} \ln \mathrm{K}_{\mathrm{d}}
\end{gathered}
$$

where $K_{d}$ is the equilibrium partition constant calculated as the ratio between sorption capacity $\left(\mathrm{q}_{\mathrm{e}}\right)$ and equilibrium concentration $\left(\mathrm{C}_{\mathrm{e}}\right), \mathrm{R}$ is the gas constant $(8.314 \mathrm{~J} / \mathrm{mol} / \mathrm{K})$ and $\mathrm{T}$ is the temperature in Kelvin (K). From eqn. 8 a plot of $\log \mathrm{K}_{\mathrm{d}}$ versus 1/T (Fig. 8) give $\Delta \mathrm{H}^{\mathrm{o}}$ and $\Delta \mathrm{S}^{\mathrm{o}}$, the calculated thermodynamic parameters are given in Table-3.

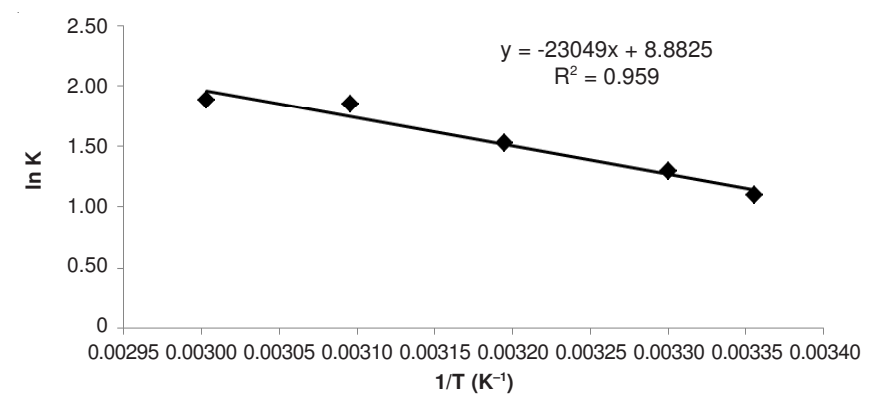

Fig. 8. Thermodynamic study of adsorption of methylene blue onto mixed waste activated carbon

\begin{tabular}{cccc}
\multicolumn{4}{c}{ TABLE-3 } \\
THERMODYNAMIC PARAMETERS OF ADSORPTION \\
OF MB ONTO MIXED WASTE ACTIVATED CARBON \\
\hline Temperature T & \multicolumn{3}{c}{ Thermodynamic parameters } \\
\cline { 2 - 4 }$(\mathrm{K})$ & $\Delta \mathrm{G}^{\mathrm{o}}(\mathrm{kJ} / \mathrm{mol})$ & $\Delta \mathrm{S}^{\circ}(\mathrm{J} / \mathrm{mol} / \mathrm{K})$ & $\Delta \mathrm{H}^{\mathrm{o}}(\mathrm{kJ} / \mathrm{mol})$ \\
\hline 298 & -6.27 & & \\
303 & -7.53 & & \\
313 & -9.12 & 158.3 & \\
323 & -11.4 & & \\
333 & -12 & & \\
\hline
\end{tabular}

The negative value of $\Delta \mathrm{G}^{\mathrm{o}}$ indicates the spontaneous nature of adsorption of methylene blue onto mixed waste activated carbon. Generally, a value of $\Delta \mathrm{G}^{\mathrm{o}}$ in between 0 and $-20 \mathrm{~kJ} / \mathrm{mol}$ is consistent with electrostatic interaction between adsorption sites and the adsorbing ion (physical adsorption) while a more negative $\Delta \mathrm{G}^{\mathrm{o}}$ value ranging from -80 to $-400 \mathrm{~kJ} /$ mol indicates that the adsorption involves charge sharing or transferring from the adsorbent surface to the adsorbing ion to form a coordinate bond (chemisorption) ${ }^{37-41}$. As shown, the magnitude of $\Delta \mathrm{G}^{\mathrm{o}}(-6.27$ to $-12 \mathrm{~kJ} / \mathrm{mol})$ which indicate a typical physical process. According to the van't Hoff equation, the standard enthalpy and the entropy values in the range of 25$50{ }^{\circ} \mathrm{C}$ were obtained as $44.13 \mathrm{~kJ} \mathrm{~mol}^{-1}$ and $158.3 \mathrm{~kJ} \mathrm{~mol}^{-1} \mathrm{~K}^{-1}$ at initial $\mathrm{pH} 5$ and initial methylene blue concentration 50 ppm, respectively. As can be deduced from Fig. 8, the positive value of $\Delta \mathrm{H}^{\mathrm{o}}$ suggests the endothermic nature of adsorption while the positive values of $\Delta \mathrm{S}^{\circ}$ indicates an increase in the degree of freedom (or disorder) of the adsorbed species. In general, the thermodynamic parameters indicate that the adsorption is spontaneous and endothermic.

Comparison of adsorption capacity of varous modified adsorbant for methylene blue: It is clear from Table-4 that by comparing maximum adsorption capacities $\left(\mathrm{q}_{\max }\right)$ of mixed waste activated carbon and other adsorbents from literature, mixed waste activated carbon have a large capacity in the removal of methylene blue from aqueous solutions. 


\begin{tabular}{lcc}
\hline \multicolumn{3}{c}{ TABLE-4 } \\
\multicolumn{3}{c}{ COMPARISON OF ADSORPTION CAPACITY OF VAROUS } \\
MODIFIED ADSORBANT FOR METHYLENE BLUE \\
\hline \multicolumn{1}{c}{ Adsorbent } & $\begin{array}{c}\mathrm{q}_{\max }(\mathrm{mg} / \mathrm{g}) \\
\left.\text { (temperature }{ }^{\circ} \mathrm{C}\right)\end{array}$ & Reference \\
\hline Activated carbon from mixed wastes & $140.03(30)$ & This study \\
Coffee husks & $90.1(30)$ & 6 \\
Yellow passion fruit waste & $44.7(25)$ & 7 \\
Rice husks & $40.6(32)$ & 8 \\
Banana peel & $20.8(30)$ & 9 \\
Cereal chaff & $20.3(25)$ & 10 \\
Spent coffee grounds & $18.7(25)$ & 11 \\
Orange peel & $18.6(30)$ & 9 \\
Wheat shells & $16.6(30)$ & 12 \\
Posidonia oceanica (L.) fibres & $5.6(30)$ & 13 \\
\hline
\end{tabular}

\section{Conclusion}

Activated carbon which is prepared by the copyrolysis of mixed solid wastes (biomass, cartons and polystyrene) and by chemical activation with $\mathrm{ZnCl}_{2}$ at low carbonization temperature showed high efficiency in removal of methylene blue from aqueous solutions. By optimizing the adsorption process, results showed that $\mathrm{pH}$ had no considerable effect on the adsorption of methylene blue. Effective adsorption was occurred in the $\mathrm{pH}$ range of 5-12. The kinetics of methylene blue adsorption followed pseudo-second order rate expressions. The adsorption of methylene blue was found to be dependent on the initial concentration. The amount methylene blue adsorbed at equilibrium increased from $10-141.03 \mathrm{mg} / \mathrm{g}$ with the increase in the initial dye concentration from 5-150 ppm. Thermodynamic parameters; $\Delta \mathrm{G}^{\mathrm{o}}, \Delta \mathrm{H}^{\circ}$ and $\Delta \mathrm{S}^{\circ}$ showed that the sorption process was spontaneous and endothermic in nature. Also D-R model confirm the physical adsorption of methylene blue onto mixed waste activated carbon.

\section{ACKNOWLEDGEMENTS}

This work was supported by NPST program by King Saud University project number 09-env656-02.

\section{REFERENCES}

1. M.S. Chiou, P.Y. Ho and H.Y. Li, J. Dyes Pigments, 60, 69 (2004).

2. D. Shen, J. Fan, W. Zhou, B. Gao, Q. Yue and Q. Kang, J. Hazard. Mater., 172, 99 (2009).

3. D. Ghosh and K.G. Bhattacharyya, Appl. Clay Sci., 20, 295 (2002).

4. M. Gladchenko, E. Starostina, S. Shcherbakov, B. Versprille and S. Kalyuzhnyi, Water Sci. Technol., 50, 67 (2004).

5. A.Z. Aroguz, J. Gulen and R.H. Evers, Bioresour. Technol., 99, 1503 (2008).

6. L.S. Oliveira, A.S. Franca, T.M. Alves and S.D.F. Rocha, J. Hazard. Mater., 155, 507 (2008).
7. F.A. Pavan, E.C. Lima, S.L.P. Dias and A.C. Mazzocato, J. Hazard. Mater., 150, 703 (2008).

8. V. Vadivelan and K.V. Kumar, J. Colloid Interf. Sci., 286, 90 (2005).

9. G. Annadurai, R.S. Juang and D.J. Lee, J. Hazard. Mater., 92, 263 (2002).

10. R. Han, Y. Wang, P. Han, J. Shi, J. Yang and Y. Lu, J. Hazard. Mater., 137, 550 (2006).

11. A.S. Franca, L.S. Oliveira and M.E. Ferreira, Desalination, 249, 267 (2009).

12. Y. Bulut and H. Aydin, Desalination, 194, 259 (2006).

13. S.-T. Ong, P.-S. Keng, M.-S. Voon and S.-L. Lee, Asian J. Chem., 23, 2898 (2011).

14. Gaballah, D. Goy, E. Allain, G. Kilbertus and J. Thauront, Met. Metall. Trans. B, 28, 13 (1997).

15. A. Hubbard, Encyclopedia of Surface and Colloid Science, Dekker, New York (2003).

16. J. Febrianto, A.N. Kosasih, J. Sunarso, Y.H. Ju, N. Indraswati and S. Ismadji, J. Hazard. Mater., 162, 616 (2009).

17. C. Sourja, D. Sirshendu, D. Sunando and K.B. Jayanta, Chemosphere, 58, 1079 (2005).

18. B.H. Hameed, J. Hazard. Mater., 161, 753 (2009).

19. M. Radhika and K. Palanivelu, J. Hazard. Mater., 138(B), 116 (2006).

20. Y. Onal, C. Akmil-Basar, C. Sarici-Ozdemir and S. Erdogan, J. Hazard. Mater., 142, 138 (2007).

21. S.L. Wang, Y.M. Tzou, Y.H. Lu and G. Sheng, J. Hazard. Mater., 147, 313 (2007).

22. B.G. Prakash Kumar, K. Shivakamy, L.R. Miranda and M.Velan, J. Hazard. Mater., 136B, 922 (2006).

23. I.A.W. Tan, B.H. Hameed and A.L. Ahmad, Chem. Eng. J., 137, 462 (2008).

24. C.M.B. Lehmann, M. Rostam-Abadi, M.J. Rood and J. Sun, Energy Fuels, 12, 1095 (1998).

25. A.M. Cunliffe and P.T. Williams, Energy Fuels, 13, 166 (1999).

26. S. Babel and T.A. Kurniawan, J. Hazard. Mater., B97, 219 (2003).

27. T.A. Kurniawan, G.Y.S. Chan, W.H. Lo and S. Babel, Chem. Eng. J., 118, 83 (2006).

28. Z.A. Al-Othman, M.A. Habila and R. Ali, In Proceedings of 2011 International Conference on Biology, Environment and Chemistry (ICBEC), Dubai, UAE, December 28-30 (2011).

29. W. Kaminsky, J.-S. Kim and B. Schlesselmann, J. Anal. Appl. Pyrol., 40-41, 365 (1997).

30. K.W. Lee and D.H. Shin, Waste Manage., 27, 168 (2007).

31. V.K. Singh and P.N. Tiwari, J. Chem. Technol. Biotechnol., 69, 376 (1997).

32. Y.S. Ho, G. Mckay, D.A.J. Wase and C.F. Foster, Adsorp. Sci. Technol., 18, 639 (2000).

33. S.K. Srivastava, R. Tyagi and N. Pant, Water Res., 23, 1161 (1989).

34. R.J. Gonzalez, J.R. Videa, E. Rodriguez, S.L. Ramirez and J.L. Torresdey, J. Chem. Thermodyn., 37, 343 (2005).

35. K. Saltali, A. Sari and M. Aydin, J. Hazard. Mater., 141(B), 258 (2007).

36. S.F. Adriana, S.O. Leandro and E.F. Mauro, Desalination, 249, 267 (2009).

37. M. Horsfall, A.I. Spiff and A.A. Abia, Bull. Korean Chem. Soc., 25, 969 (2004)

38. Z.A. AlOthman, A. Hashem and M.A. Habila, Molecules, 16, 10443 (2011).

39. J.M. Smith and H.C. Van Ness, Introduction to Chemical Engineering Thermodynamics, McGraw-Hill, Singapore, edn. 4 (1987).

40. E. Malkoc and Y. Nuhoglu, Chem. Eng. Process, 46, 1020 (2007).

41. D. Sigh, Adsorp. Sci. Technol., 18, 741 (2000). 